\title{
TRANSLATORS UP A (PLUM)TREE: (FOOD)NOTES TO THE TRANSLATION OF THE 'SANDWICH PASSAGE' INTO HUNGARIAN AND ROMANIAN
}

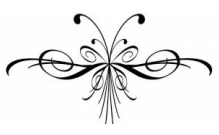

ERIKA MIHÁLYCSA

$\mathrm{F}$ rom the perspective of translation, Lestrygonians is a chapter that goes in the face of linguistic norm, subverting expectations of standard language use. The chapter consistently shows meaning to be unstable, self-generating along lines of flight, mushrooming around nodes of (semantic) tension. The cohesion of the text, as shown in the 'sandwich' passage, depends on a series of such nodes, of linguistic occasions, associations and interfaces; Bloom's associations and bricolage (or, to use Jean-Michel Rabaté's pun, brick-holing) ${ }^{1}$ of words which direct and channel the text's movements are called forth by the shape of phrases, homonymy and polysemy. Such instability of meaning and of the directions of the production of meaning certainly musters and breeds translation problems: the translator would have to aim at finding/ creating analogous interfaces in the target language (TL) that could account for, and function as points of departure for Bloom's strings of associations, for the text's nodes of meaning and tension. The TL text, in short, would have to empower a series of punceptual relationships ${ }^{2}$ that could generate the text, while being conditioned by such interfaces, nodes of meaning as the TL possesses.

Probably no other single work of modern English literature had such a transforming effect on the perception and use of language as Joyce's Ulysses, and this to no slight extent due to its polytropic defamiliarizing effects. The translations enlisted for this comparative discussion show different strat-

${ }^{1}$ Rabaté, Jean-Michel. James Joyce, Authorized Reader (Baltimore \& London: Johns Hopkins University Press, 1991), p. 3.

${ }^{2}$ Dettmar, Kevin J.H.. The Illicit Joyce of Postmodernism. Reading against the Grain (The University of Wisconsin Press, 1996), p. 143. 
egies for inventing a language that attempts to elicit comparable effects. In my case study on the Romanian, and the three existing Hungarian translations of the 'sandwich passage' in 'Lestrygonians', I will try to enlighten these strategies at a microtextual level, the translation versions addressed being Mircea Ivănescu's Romanian Ulise (1984), as well as the Hungarian versions of Endre Gáspár (1947), Miklós Szentkuthy (1974) and the recent Hungarian translation carried out by a team of Joycean scholars and critics (Marianna Gula, András Kappanyos, Dávid Szolláth, Gábor Zoltán Kiss) that takes the two previous translation versions as its point of departure, and which I will refer to as the "Corrected" text. ${ }^{3}$

Poet and translator Mircea Ivănescu's Romanian Ulise, first published in instalments starting in 1971 and issued in two volumes in 1984 with the translator's annotations, has long been hailed among the highest achievements of literary translation into Romanian, especially by virtue of the 'domesticating' rendering of 'Oxen of the Sun' which transposes Joyce's parodic enlisting of the English historical prose styles to the ontogenetic evolution of the Romanian language. Ivănescu's text, most successful when addressing the more outwardly experimental episodes, used Gifford and Seidman, Ellmann's biography, as well as the work of Zack Bowen as props; in its overall effect, it shows 'a linguistic resourcefulness, musical ear and ludic spirit that Joyce himself always favoured when supervising the translation of his work' ${ }^{4}$ Among its most obvious shortcomings one has to mention an unevenness between the two volumes, as seen also in the discrepancy in annotation: in the second volume, a meagre 6 notes correspond to the first volume's full-blown scholarly apparatus of 337. Partly constrained by the inflective grammar of Romanian, Ulise also tends to disambiguate the indirections and indeterminacy of Joyce's syntax, often turning out wellrounded discursive sentences in place of the original's ellipses and gaps; similarly, there is a tendency towards explicitation and semantic overdetermination. As Laurent Milesi and Arleen Ionescu, the authors of the

${ }_{3}^{3}$ All references are to the following editions: James Joyce, Ulysses, transl. Endre Gáspár (Budapest: Nova Irodalmi Intézet, 1947, I-II), hereafter (HU/Gáspár); James Joyce, Ulysses, transl. Miklós Szentkuthy, ed. Endre Bartos. 2nd edition (Budapest: Európa, 1986), hereafter (HU/Szentkuthy); James Joyce, Ulysses, transl. András Kappanyos, Marianna Gula, Dávid Szolláth, Gábor Kiss (Budapest: Arktisz, 2010), hereafter (HU/"Corrected"), and James Joyce, Ulise, transl. Mircea Ivănescu (Bucureşti: Univers, 1984, I-II), hereafter (RO/Ivănescu).

${ }^{4}$ Adrian Oţoiu, "'Le sens du pousser": On the Spiral of Joyce's Reception in Romania', in The Reception of James Joyce in Europe. Vol. I: Germany, Northern and East Central Europe, eds. Geert Lernout, Wim van Mierlo (London - New York: Thoemmes Continuum, 2004), 198-213, p. 203.

Scientia Traductionis, n.8, 2010 
most insightful study of Ivănescu's text to date show on a series of examples, Ivănescu's translation version also falls short of the original's effects of linguistic and stylistic defamiliarization, as well as 'taming' Molly's soliloquy and generally tuning down the shock-effect of the notoriously 'scandalous' novel by supplanting salacious words with euphemisms and heightening the register. ${ }^{5}$

As regards the Hungarian translations, the first Hungarian version of Ulysses by Endre Gáspár appeared in the unlikely year 1947, in 1000 numbered copies teeming with typos, just like the 1922 text. As the historical climate could hardly have been less propitious and the Irish novelist's work was virtually unknown in the Hungary of the 1930s, Gáspár's Ulysses never ran to a reception history proper and didn't become embedded in cultural memory. Part of the lack of response may have been due to the Gáspár text's lacklustre quality, which obviously falls short of the trans-luding that Joyce's text demands from the translator, especially as regards the rendering of the stylistic and linguistic plurivocity. There is a leaning towards (even excessive) literalization, to the extent that it is difficult to assess whether Gáspár's, occasionally stunning, reproduction of the ruptured, elliptic syntax and linguistic anomalies of the Joycean interior monologue are due to a selfconscious translatorial strategy or rather, to a mechanical faithfulness to the original. Among the text's virtues one has to point out the clarity of the pattern of structural connections, internal echoes, as well as the sound background of English and Irish culture and a remarkable sense of (idiomatic) language - not to be taken for granted with the work of early translators who didn't have the advantage of much of Joycean criticism and whose access to information was precarious.

If Gáspár can be described as a literalist, then Miklós Szentkuthy's 'authoritative' Hungarian translation is rather on the side of the belles infideles - to the extent that it often pushes the question of the faithfulness of translation to the limits. The novelist whose own, baroque metafictional work (most notably the novel Prae, 1934) suffered as much as it profited from the all-too-easily given label 'the Hungarian Joyce', created an intensely musical, stylistically vibrant translation text that revels in language games, and is suffused with a Gargantuan humour. As he himself wrote in an essay, no translation can aim to be the mirror image of Ulysses but rather, the translator has to 'play chess' with the original - although he warns of the

${ }^{5}$ Laurent Milesi and Arleen Ionescu, 'The "Experience" of Ulysses in Romanian', in $\mathrm{Pa}$ pers on Joyce 14 (2008), 85-114. 
danger of 'over-Ulyssesizing' ${ }^{6}$ Often, however, the selfsame features that earned Szentkuthy's text the adjective (and legend) 'congenial' prove to be its most blatant shortcomings: the author's self-generating word-machine and stylistic virtuosity tends to take over, inserting gratuitous puns and points while disregarding important structural connections. As András Kappanyos and Dávid Szolláth convincingly demonstrate on a series of examples, Szentkuthy's text frequently lacks in plurivocity and fails to render the semantic layering of Joycean choice words, his ostentatious verbal sparkles contribute to a homogenizing of style, language, and register, as most characters tend to speak the 'Szentkuthyan' idiom only. ${ }^{7}$ One of the most painful fallacies is the carelessness for structural and stylistic fine-tuning, vital for the sense of the intricate interrelations among the episodes, and often the reader's only tool for recuperating the 'plot'. Thus, the characters' Homeric attributes are subject to wide variation across the episodes; an odd name that generates semantic nuclei, like the horse Throwaway or the man in the mackintosh, are not dealt with satisfactorily, the Hungarian Ulysses becoming, by and large, more 'unreadable' than the original. The treatment of Joycean indeterminacy, of the elliptic, porous structure of interior monologues is also very uneven and hardly the product of a consistent strategy: whereas Szentkuthy occasionally makes a point of creating

${ }^{6}$ Miklós Szentkuthy, 'Miért újra Ulysses?' [Why Ulysses again?], in Nagyvilág (February 1968), 274-79. For the history and reception of the Hungarian translations of Ulysses see Márta Goldmann, 'Belated Reception: James Joyce's Works in Hungary', in Comparative Critical Studies 3, 3 (2006), 227-248.

${ }^{7}$ Cf. András Kappanyos, 'Ulysses, a nyughatatlan' [Ulysses the restless], in Átváltozások 10 (1997), 44-54, as well as the lectures delivered by the members of the translator team of the "Corrected" text at the conference organized by the Hungarian Academy of Sciences, January 20, 2010, available on the homepage of the institution: András Kappanyos, 'Joyce mint klasszikus auktor és mint magyar invenció' [Joyce the classic and Joyce the Hungarian invention], http://www.mta.hu/fileadmin/I_osztaly/eloadastar/KappanyosA_Ulysses.pdf; Dávid Szolláth, 'Leletmentés: válogatott szentkuthyzmusok az Ulysses szövegében' [Archiving the finds: selected 'Szentkuthysms' in the Ulysses text], http://www.mta.hu/fileadmin/I_osztaly/eloadastar/SzollathD_Ulysses.pdf. Whereas no comprehensive critical study on the existing Hungarian translations is available yet, a valuable assessment of the differences between Gáspár's and Szentkuthy's Hungarian version of 'Oxen of the Sun' was published by Joycean scholar Péter Egri following the publishing of Szenkuthy's translation, in which he demonstrates that Gáspár, faithfully following the original, fails to capture the poetic valences of the text, while Szentkuthy tries to out-Joyce Joyce himself, being incomparably more sensitive and creative to the work as a whole, but less exact in the rendition of detail: 'Szentkuthy Miklós Ulysses fordításáról' [On Miklós Szentkuthy's translation of Ulysses], in Nagyvilág 3 (1974), 43337. 
breaches in Hungarian syntax, and of signalling defamiliarizing effects, on other occasions linguistic, as well as stylistic, anomalies are smoothed out. ${ }^{8}$ In contradistinction to Ivănescu, Szentkuthy also tends to heighten the text's bawdiness and to lower the register.

The "Corrected" Hungarian translation grew out of a joint project initiated by Joycean scholar András Kappanyos, of revising Szentkuthy's translation, but it soon overstepped the self-imposed limits and turned into a veritable retranslation which takes the two previous translations as its points of departure. ${ }^{9}$ One of the main objectives of the translator team (Joycean scholars Marianna Gula, András Kappanyos, and critics Dávid Szolláth and Gábor Zoltán Kiss) was to restore to the Hungarian text the vital network of structural, stylistic and (intra-)intertextual correspondences, to carry out a fine-tuning with an eye to the original's (stylistic, linguistic) polyphony..$^{10}$ The upcoming text - the methodology and some of the gains of which are discussed in Marianna Gula's insightful essay ${ }^{11}$ - obviously draws on a vast corpus of Joycean scholarship; it addresses semantic obscurities and is likely to favour more radical (stylistic, linguistic) interventions.

The 'sandwich passage' is a muster of language games, semiosis resulting from the juxtaposition of heterogeneous shreds of language, associa-

\footnotetext{
8 Szentkuthy's translation text went into a second edition in 1986 edited by Tibor Bartos who tampered with the text; the extent of Bartos's (often arbitrary) editorial intrusions is difficult to assess but, contrary to the editor's note acknowledging a revision of the 1974 translation text on the basis of the Gabler edition (1984), a quick scan of the text reveals no trace of revisions justified by the significant textual emendations in the Gabler edition (Ferenc Takács, oral communication).

9 The project and methodology of a team retranslation of Ulysses was announced by András Kappanyos in 'Megint egy work-in-progress: a magyar Joyce-kiadás és a Magyar anglisztika' [A work-in-progress again: the publishing of Joyce and English studies in Hungary], in Filológiai Közlöny 3-4, 245-250; judging by the present text, it is largely the product of retranslation, less than half of it being based on Szentkuthy's/Gáspár's version. Although issued (in 10 numbered copies) on January 20, 2012, the "Corrected" Hungarian text is still partially a work-in-progress, thus changes may occur before the planned publication in 2012; a second volume of annotations is also in preparation.

10 Some of the "Corrected" text's solutions for recurring names, distorted quotes and other (intra-)intertextual echoes, translators' cruxes are discussed in András Kappanyos's article 'At the End of One's Witz (Translation Theory and Some Practice)', in Papers on Joyce 14 (2008), 39-50.

11 'A fordítás során keletkező ,hozzáadott érték” jelenségéről' [On the phenomenon of translatorial Mehrwert]: http://www.mta.hu/fileadmin/I_osztaly/eloadastar/GulaM_Ulysses.pdf. A revised and expanded English-language version of the Hungarian conference lecture, under the title 'Lost a Bob but Found a Tanner: From a Translator's Workshop' is part of the James Joyce Translation dossier published on this very issue of Scientia Traductionis.
} 
tions freely flowing in interior monologue; such interfaces, meetings allow for a re-interpretation of words/phrases in multiple directions. The first and arguably greatest untranslatability in the passage rests on the homonymy of 'ham' and the (English version of the) Biblical name Ham that occasioned an English joke. It is highly unlikely, however, that the authors of the translations considered here (with the obvious exception of the "Corrected" Hungarian text) have been aware of the origin of the homonym, the riddle. ${ }^{12}$ An additional irony of the sentence is that the name of a character from Deuteronomy and a (mock-scripture) phrase is grafted onto an image of food forbidden to orthodox Israelites, by the (linguistic) association of an apostate Jew - as if in a tongue-in-cheek reminder that 'man doth not live by bread only' (Deuteronomy 8:2-3, KJV):

Sandwich? Ham and his descendants mustered and bred there. (8.742)

The translators whose language does not offer any homonyms on Hebrew Bible characters and names of food have two options: either to limit themselves to the contextually unproblematic 'ham', 'mustard' and 'bread', as did the translators of the two Hungarian versions, Endre Gáspár and Miklós Szentkuthy, or to preserve the Biblical name and an apparently scriptural phrase, as did the Romanian translator, Mircea Ivănescu:

\footnotetext{
HU/ Gáspár: Szendvics? Sonka és társai szép sorban, mustárral. (I/135) Sandwich? Ham [meat] and company lined up neatly, with mustard.

HU/Szentkuthy: Szendvics? Ez a sonka sok élősdit fölnevelt. (219) Sandwich? This ham [meat] has bred many parasites.

RO/Ivănescu: Un sandvici? Ham şi toţi cei care se trag din el s-au strâns şi s-au înmulţit aici. (I/203)

A sandwich? Ham [Bible character] and all who descend from him have gathered and multiplied here.
}

Since in the Romanian version there is no wordplay involved, the essential element on which the original's effect rests is lost; the reader is given no clues as to the connection point between the display of food and the Bible text inscribed on it. Similarly, Szentkuthy, in an attempt to carry across as

12 "Why should no man starve on the deserts of Arabia?/ Because of the sand which is there./ How came the sandwiches there?/ The tribe of Ham was mustered and bread there' (emphases added). 
much of the original meaning as possible, produces a sentence that stands out contextually and can only function with a background knowledge of the English original's 'mustered and bred'. The reader is at a loss as to why the sight of ham should bring parasites to Bloom's mind and there is no allusion whatsoever to the fact that the sentence stands for a double-decker utterance in the original. The effect is either nil (Gáspár) or of confusion, lack of connectedness (Szentkuthy, Ivănescu) - a confusion that is, moreover, markedly different from the (rhizomatic) network of confusion generated by the original text.

An attempt at rendering the homonymy, the linguistic interface which allows for a double reading is made in the 'Corrected' Hungarian version:

HU/'Corr': Szendvics? Hám hozza sarjait, hogy feltegye őket magas szekerére.

Hámozza sajtjait, hogy feltegye őket vajas kenyerére.

Ham [Bible character] brings his issue to put them on his high chariot.

[Subj] peels [his] cheese to put [them - the slices] on [his] buttered bread.

This version aims at substituting the link 'Ham, mustered, bred' 'ham, mustard, bread' with two sentences whose pronunciation is similar in Hungarian, the first one having a distinctive mock-scriptural ring. Although this cluster assumes a rather improbable mental association (both sentences lacking the effect of linguistic spontaneity as well as a certain ring that would make for catch-phrases or jokes easy to remember), as translation it nevertheless succeeds in signalling the working of language in the original.

\section{'Something galoptious' (8.664): translators' cruxes}

The 'sandwich passage' could be anthologized as an example of the complexities, dislocutions, process/impact-sentences and general deviations from norm that make Ulysses such a richly rewarding reading. ${ }^{13}$ To begin

${ }^{13}$ I am using Fritz Senn's terms: 'dislocution', as introduced in 'Variants of Dislocution' (Nichts gegen Joyce/ Joyce versus Nothing, Zürich: Haffmans Verlag 1983, pp. 125-142); 'sent', process/impact-sentences as consecrated in Dislocutions: Essays on Reading as Translation (Baltimore: Johns Hopkins University Press 1984), pp. 199-211; 'Syntactic Glides', in James Joyce and the Difference of Language, ed. Laurent Milesi (Cambridge: Cambridge University Press, 2003), 28-42; 'Dynamic Changes: Ulysses in Practice', in Ida 
with, it shows an intimidating number of cruxes that would send all translators up the (plum)tree: from (unwitting) language effects that unveil textual tensions to language games that exploit homonymy, polysemy, and literal and figurative readings of idiomatic constructions.

From among the various language games and language effects, five struck me as the most clearly untranslatable. Number one:

Lord knows what concoction. (8.749; emphases added)

Here the word itself discloses what the (incompletely remembered) limerick that follows plays at hiding, or euphemising ('the parts of honour', 'the somethings of the Reverend Mr McTrigger', where the rhythm obviously calls for a one-syllable word); moreover, a similar cock-word occurs in the vicinity of the limerick in the sentence, 'Cannibals would with lemon and rice' (8.745). It may well be the text's unconscious that manifests itself in the choice of words or, to use Deleuzian terms, in the pass-words beneath order-words (the line of cock-words starting with Paul de Kock's 'nice name' in Calypso, 4.358). ${ }^{14}$ Such play with meanings is, needless to say, utterly untranslatable. ${ }^{15}$

The second example of untranslatability:

His wives in a row to watch the effect. (8.747; emphases added)

The sentences that function as the context of the McTrigger limerick take over some of its double-decker effect, triggering a reading that has an

Klitgard (ed.), Angles on the English-Speaking World 6. Literary Translation: World Literature or 'Worlding' Literature? (University of Copenhagen: Museum Tusculanum Press, 2006), 69-82.

14 'There are pass-words beneath order-words. Words that pass, words that are compontents of passage, whereas order-words mark stoppages or organized, stratified compositions. A single thing or word undoubtedly has this twofold nature: it is necessary to extract one from the other - to transform the compositions of order into components of passage.' In Deleuze, Gilles and Félix Guattari. A Thousand Plateaus. Translation and Foreword by Brian Massumi. (London - New York: Continuum, 2004), p. 122.

${ }^{15}$ Here Hungarian allows for a similar language effect that rests on a sliding consonant: if, instead of 'kotyvasz' (n)/ 'kotyvaszt' (v) (concoction/to concoct), 'kotyfasz'/'kotyfaszt' is used, the slippery pronunciation yields the Hungarian taboo word for penis. The mispronunciation of ' $\mathrm{v}$ ' as ' $\mathrm{f}$ ' is an error commonly associated with the Hungarian of (especially German-speaking) foreigners. However, such 'explicitation' of an undisclosed pass-word in translation would be highly problematic, not to mention the nefarious connotation of rendering Bloom a foreigner in the language he uses.

Scientia Traductionis, n.8, 2010 
eye on double-entendre. Depending on the pronunciation, the phrase 'in a row' reads both as 'lined up' and 'quarreling, fighting' - the second especially ironic, considering the disputed effect. Such cases are clearly untranslatable. The possibility of re-producing sentences in the TL that read more than one way depends on the possibilities of the TL in question.

Similarly, at least two instances of linguistic byplay and untranslatability are lurking in the seemingly harmless cluster:

Religions. Christmas turkeys and geese. Slaughter of innocents. Eat drink and be merry. (8.753)

Bloom's thoughts wandering from the sight of sardine boxes to Christmas dinners project religious language onto food, to the extent that one of the phrases is a quote from Ecclesiastes, 8.15: 'Eat drink and be merry'. In a continuous shift of perspective, the smallfowl of traditional Christmas meals takes on the martyrial aura of the innocents slaughtered in Bethlehem. Moreover, since the etymological roots of 'Christmas' and 'turkey' Christ(ian), Turk(ey) - connote religions that are as a rule at variance, the covert semantic tension generated by the sequence throws an oblique light on the 'peace and war' depending on 'some fellow's digestion'. As one of the main themes around which the chapter revolves is eating, the connections between food, the (sexual) body, death and the sacred are pervasive. ${ }^{16}$

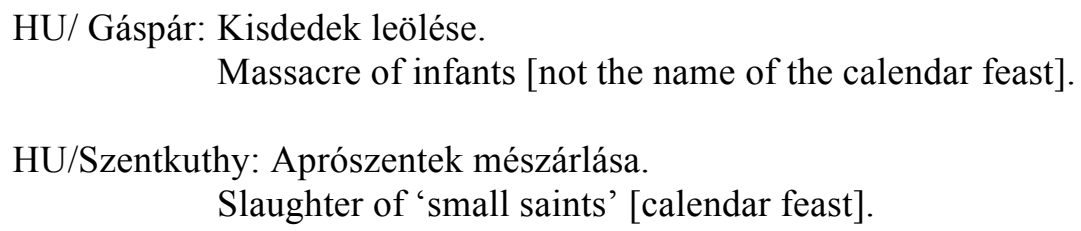

${ }^{16}$ A similar wordplay recalls a legend on the drowning of an Irish king, while also playing on the central ritual of Christianity - of the Eucharist; as such, it presents an uneasy analogy with the McTrigger limerick: 'The last pagan king of Ireland Cormac in the schoolpoem choked himself at Sletty southward of the Boyne. Wonder what he was eating. Something galoptious. Saint Patrick converted him to Christianity. Couldn't swallow it all however' (8.663, emphasis added). The translations have to play on the same duality of swallowing (food) and stomaching (e.g. a religion based on stomaching/swallowing the transubstantiated body of Christ). Since an analogous idiom, playing on the literal and figurative meaning related to swallowing exists both in Romanian and Hungarian, the irony can be carried across without loss: HU/ Gáspár: De nem ment le egészen a torkán. (I/134) [Still, it didn't wholly go down his throat.]; HU/Szentkuthy: Mégse sikerült neki lenyelni. (216) [ However, he didn't manage to swallow it.]; HU/"Corrected": Mégis a torkán akadt. (150) [Still, it stuck in his throat.] RO/Ivănescu: Însă vezi că n-a putut să-1 înghită chiar cum trebuia." (I/201) [Yet he couldn't quite swallow it as he should have.] 
HU/"Corrected": A kisdedek mészárlása.

Slaughter of the infants.

RO/Ivănescu: Uciderea pruncilor.

Massacre of infants [partial name of calendar feast; name of iconographic theme].

In translation the name of the calendar feast (and/or iconographic theme) conditions the possibility of making this encounter not only semantically but also linguistically meaningful: as the calendar feast in many TLs speaks of 'infants' rather than 'innocents', 'turkeys and geese' are apparently excluded. Szentkuthy's version, while retaining the feast name, makes possible such a connection of 'small saints' with 'smallfowl'.

The fourth example of untranslatability, the often-quoted 'mity cheese' (8.755), plays with inscribing a covertly religious meaning onto an adjectival phrase that qualifies food: the cluster can be read both as 'runny' cheese (Bloom orders a Gorgonzola sandwich) and as 'mighty' cheese (which sounds nearly homonymous with 'mighty Jesus'), a meaning corroborated by the belief that cheese helps in digesting other food. Since before the Gabler edition the phrase was routinely 'corrected' to 'mighty', the early translations have only this possibility in view, aiming at a play on divinity as far as possible. Accordingly, the Hungarian versions of Gáspár (Hatalmas sajt ['Mighty cheese'], I/135) and Szentkuthy, whose version is taken over into the "Corrected" text (Ó, sajtok sajtja ['O, cheese of all cheeses'], 219), add an ironic touch to might.

Playful side-effects in translation result from foreign-language versions that exploit some kind of linguistic overlapping at work: in the Romanian translation for instance, the word used for 'might' (putere) includes the root-word of the verb 'to stink' (a pute/ putoare), squinting thus at 'the feety savour of green cheese' (8.819):

RO/Ivănescu: Mare putere are brânza. (I/204)

Great might [strength] this cheese has.

\section{'What a stupid ad' (8.742)}

In line with the four untranslatabilities mustered here, my fifth example relates to the multiple linguistic associations that bring together the Plumtree advertisement slogan, placed under the obituaries, with the idiom '(to be) up a (gum)tree' - i.e., in great difficulty - and ultimately lead to the 
association of Dignam's death with potted meat, which in turn calls forth the euphemistically bawdry limerick on cannibalism. Conditioned by the name 'Plumtree' in the advertisement, translators are put in the well-nigh impossible position of having to translate 'plumtree' in order to drive the allusion home, and then turn out some version that brings into play an existing idiom in the TL that has a plumtree or some fruity relation in it. Moreover, plums can't arbitrarily be changed, as they also recur elsewhere in Ulysses in contexts closely connected to the sexual body: in Bloom's interior monologue in 'Nausicaa', obviously referring to Molly and Boylan ('He gets the plums and I the plumstones', 13.1098), as if in an ironic inversion of the plumstones falling on barren ground beneath Nelson's Pillar, in Stephen's Parable of the Plums. ${ }^{17}$

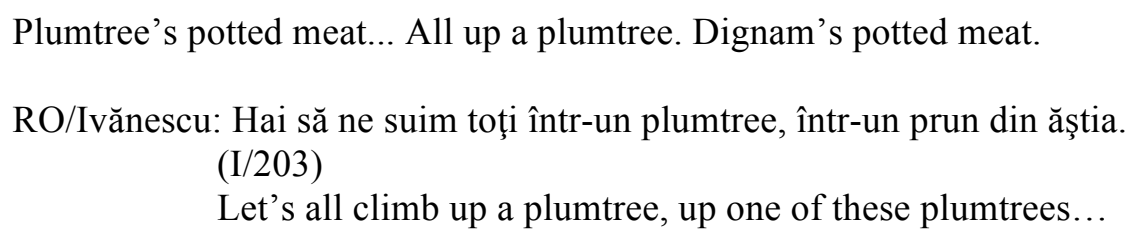

Whereas Szentkuthy sidesteps the problematic phrase altogether, the Romanian translation follows the original's string of associations literally, explicitating 'plumtree'. However, since there is no idiomatic meaning for 'climbing up a plumtree', the sentence that should function as a mental link between the Plumtree ad and Dignam's death remains unexplained. On the other hand, the first Hungarian translation speaks of the constraint of finding a solution: the idiom it distantly recalls is '(olyan képet vág, mint aki) vackorba harapott' [(to pull a face as one who) took a bite of a wild pear], used in situations where things turn out badly, sourly, contrary to what was expected, resulting in dissatisfaction ('wild pear' is also used for something worthless, useless).

HU/"Corrected": Kivágták alóla a szilvafát. (151)

[They] cut the plumtree from under him.

\footnotetext{
${ }^{17}$ The Plumtree ad is fully reiterated in 'Ithaca', followed by the elucidation and anagrams, 'The name on the label is Plumtree. A plumtree is a meatpot, registered trade mark. Beware of imitations. Peatmot. Trumplee. Moutpat. Plamtroo' ( $U$ 17.604).
} 
The "Corrected" Hungarian text operates with the transfer Plumtree - szilvafa, and brings into play a 'faked' idiom - similarly to the original where (gum)tree is supplied with plumtree. The tree-idiom tampered with is 'maga alatt vágja a fát' ('to be cutting the tree beneath oneself' meaning, to be ruining one's own life/prospects); with the change of the subject ( $3^{\text {rd }}$ pers.) and of the tense (perfect), the person referred to becomes the sufferer of an irrevocable change for the worse. The structural connection between the Plumtree ad and the (manipulated) saying is driven home, the reader is offered the cues which make it possible to follow the nodal logic of ellipses and porousness which governs Bloom's mental associations.

The backbone of the passage which generates a lateral proliferation of meaning is the interrelation between the recurring Plumtree ad and the McTrigger rhyme. Whereas the Plumtree slogan is 'remembered' from 'Lotus Eaters' and reproduced fragmentarily, the limerick is broken into two incomplete fragments, its rhyme and upset rhythm pattern pointing at the pious ellipsis, a drop of a one-syllable word in the second verse. The Plumtree ad's first catchy, rhyming verses are recalled together with an utterance that also appears earlier: that the advertisement was 'stuck' under the obituary notices (8.138). It is essential that the translation text, too, 'remembers' the ad and the rhymes.

Lotus Eaters: What is home without/ Plumtree's Potted Meat?/ Incomplete./ With it an abode of bliss. (5.144)

Lestrygonians: 'Potted meats. What is home without Plumtree's potted meat? Incomplete. What a stupid ad! Under the obituary notices they stuck it. All up a plumtree. Dignam's potted meat. '

\author{
Lotus Eaters \\ RO/Ivănescu (I/87) \\ Ce e un cămin fără \\ What is home without \\ Carnea-n conserve Plumtree? \\ Plumtree's potted meat? \\ E nedesăvârşit. \\ It's imperfect.
}

\section{Lestrygonians}

RO/Ivănescu (I/204)

Ce este un cămin fără

What is home without

Conservele de carne Plumtree?

Plumtree's potted meat?

Un cămin incomplet.

An incomplete home. 
Dar cu ea, un cămin al fericirii.

But with it [her], an abode of happiness.
$\mathrm{Cu}$ el, un adevărat paradis.

With it [him], a true paradise.

The Romanian translation proposes one rhymeless slogan and a chiming promotional rhyme 'Plumtree - fericirii', an inconspicuous $a b c B$ pattern, with slight differences in prosody between them; the impact of the slogan derives from its strong alliterative spin. As none of the keywords is reproduced ('imperfect' and 'incomplete' are used at variation), alliteration should carry the catchy character of the original.

HU/ Gáspár (I/57)

Plumtree-féle húskonzervvel

With Plumtree's potted meat

Az élet lakzi, nász,

Life is a feast, a nuptial,

De nélküle a $h a ́ z$

But without it the house [is]

Gyász.

Mourning.
HU/ Gáspár (I/135)

Plumtree húskonzervje nélkül

Without Plumtree's potted meat

...Vele az élet lakzi, nász.

With it, life is a feast, a nuptial.

Otthonával meg nem békül.

With your home you cannot be reconciled.
HU/Szentkuthy (92)

Mit ér az ebédem

What is my lunch worth

Ha nincs hozzá Plumtree húskonzerv?

If there is no Plumtree's potted meat?

Keserv.

Sorrow.

Ha van: második Éden. If there is: a second Eden.
HU/Szentkuthy (219)

Mit ér az ebédem

What is my lunch worth

Plumtree húskonzerv nélkül?

Without Plumtree's potted meat?

...Áldólag benne.

Blessingly in [it]. 
HU/"Corrected" (93)

Plumtree-féle húskonzerv:

Plumtree['s] potted meat:

Nélküle mit ér az otthona?

Without it, what is your home worth?

Szinte keserv.

Almost sorrow.

Ha van: boldogság hona. If there is, the abode of happiness.
HU/"Corrected" (152)

Plumtree húskonzerv:

Plumtree potted meat:

Nélküle mit ér az otthona?

Without it, what is your home worth?

Kész keserv.

Indeed sorrow.

Ha van: boldogság hona.

If there is, the abode of happiness.

Gáspár's version repeats the rhyme with a change: one can see how the mention of 'nuptial' plays on the McTrigger limerick, with its follow-up: 'His five hundred wives. Had the time of their lives... It grew bigger and bigger and bigger' (8.778). Likewise, one can see how the new context has also occasioned the changed rhyme: whereas the 'Lotus Eaters' version has an $a b b b$ rhyme pattern, the 'Lestrygonians' version changes this to a $c c b$, recycling the second verse of the Lotus Eaters variant as its closing verse. On the whole, the jumping lines of unequal syllables united in end rhymes sound both catchy and silly - catchy enough to be remembered during the day (yet the text does not remember them; the reader wouldn't see the identity of the two rhymes, but for the name Plumtree), and silly enough to be called a 'stupid ad'. Szentkuthy's 'authorized' Hungarian version, on the other hand, not only fails to remember the verses, but in the 'Lotus Eaters' version harnesses what seems like a casually prosaic phrase with a recondite consonantal rhyme. The effect, four lines of unequal length whose rhyming $(a b b a)$ is perceived more visually than aurally, is both too prose-like and too artificial to be catchy. Small wonder the translator didn't remember it over the span of two chapters. The final verse of the second, changed version doesn't even indicate a connection to the Plumtree ad, but seems rather an extension of the McTrigger limerick; such an advertisement slogan would be not as much 'stupid' as 'phoney'.

The "Corrected" Hungarian version tampers with Szentkuthy's solution, restoring the structural connection between the two episodes. The rhyme pattern is changed to $a b a b$, with the recycled consonantal rhyme ' $k o n$ zerv-keserv' and the conspicuously facile 'otthona-hona', nearly a repetition of the word; coupled with the limping meter, the rhyme adds the slogan a humorously amateurish touch, likely to be deprecated by Bloom. 
The Plumtree ad is not the only advertisement slogan to pop up in the context of the 'sandwich passage'. Earlier in Lestrygonians we have another reminiscence of Plumtree's potted meat and a reflection on the way advertisements are written and placed; in this case, the props of involuntary memory are visual rather than aural: 'Under the obituary notices they stuck it' (8.744). The grotesque coupling of potted meat with death conditions the association 'Dignam's potted meat' when Bloom recalls another example of a memorable and misplaced slogan: 'His ideas for ads like Plumtree's potted meat under the obituaries, cold meat department. You can't lick 'em. What? Our envelopes' (8.138, emphases added). The effect of the ad depends on the impact of the first, riddle-like sentence, which is followed by the second as a dénouement. This impact is exploited in both Hungarian translations:

\author{
HU/ Gáspár: Ne nyaljon! Mit? Mást, mint a mi borítékunkat. (I/122) \\ Don't lick! What? Anything but our envelopes.
}

HU/Szentkuthy, HU/"Corrected":

Nem kell nyalni. Mit? A mi borítékainkat. $(196,137)$

You needn't lick. / You shouldn't lick! What? Our envelopes.

In Hungarian, 'to lick ([at] somebody)' has as first connotation a low colloquial idiom, 'to lick somebody's footsoles/ass' meaning, to pay lipservice, to act in a repugnantly servile manner. As an advertisement slogan, the eye-catching exhortation 'don't lick' or the, ironically exhortative, 'you needn't/shouldn't lick' produces a linguistic shock-effect which is then innocently played down with a (rolling) eye to the reader, in a tongue-in-cheek honi soit qui mal y pense fashion. In order to achieve this, Gáspár changes the message of the ad completely: instead of some, presumably innovative, envelopes with a glued appliance, the advertised envelopes which can be licked innocently would be like all other envelopes; the reassurance of morally unobjectionable licking is more important than innovation in beginning-of-20th-century design. As encoded in the Hungarian word for translation (forditás, related to 'turning' [over, inside out etc.]), the act of translation, rather than transferring, turns not only the text, but also its corresponding referential world $-a$ world of many turns. 


\section{'Effect on the sexual' (8.866)}

The Plumtree ad's grotesque location triggers forth a chain of associations with cannibalism, leading to the inscription of the limerick onto the Plumtree rhyme. Linguistic form is thus 'contaminated' by the interface: cannibalistic imagery is rendered in what could be read as Bloom's mental version of the chieftain's voice, in something approaching pidgin English: 'White missionary too salty'. There is a sense of a contamination of voices and language use, as if the 'much-turned' hero were mentally ventriloquizing in the act of conjuring up the context of a remembered rhyme. ${ }^{18}$ The limerick plays on sexual cannibalism, its trigger-word being the (very reverend) name McTrigger. Gáspár's and Szentkuthy's Hungarian translations accordingly preserve the nigger - McTrigger rhyme which, understandably, doesn't invite a 'reading between the lines', so they have to create the double entendre by some other means.

(1) There was a right royal old nigger.

(2) Who ate or something the somethings of the reverend $\mathrm{Mr}$ MacTrigger.

With it an abode of bliss.

Lord knows what concoction. (8.742)

(3) His five hundred wives.

(4) Had the time of their lives. (...)

(5) It grew bigger and bigger and bigger. (8.778)

18 One cannot, however, exclude here a general pattern of ungrammaticality: the modal construction in the previous sentence is elliptical, but ironed out in all translation versions examined by me, through the filling in of a main verb closest to linguistic expectations: HU/ Gáspár: „Kannibálok citrommal és rizzsel rendelnék.” [Cannibals would order it with lemon and rice...]; HU/Szentkuthy, HU/”Corrected”: „Kannibáloknak izlene citrommal és rizzsel.” [Cannibals would like it with lemon and rice.]; RO/Ivănescu: „Canibalii i-ar pune şi lămâie şi garnitură de orez." [Cannibals would add to it lemon and rice also.] The only translation version that attempts to render the felt ungrammaticality of "White missionary too salty' is Gáspár's: the deletion of the definite article ("Fehér hittérítő túl sós") signals a deviation from norm sensed in the original. 
HU/ Gáspár: (1) Volt egyszer egy vén királyi nigger.

There was once a royal old nigger.

(2) Az ő gyomrába vándorolt főtisztelendő urunk, Mac Trigger.

Into his stomach migrated our Very Reverend Mac Trigger.

Vele az élet lakzi, nász.

With [it/him] ife is a feast, a nuptial.

Tudja a jó Ég, micsoda keverék. (I/135)

Heaven knows what mixture.

(3) Mind az ötszáz kicsi nője

All his five hundred little women

(4) Nagyot evett belöle.

Ate their fill from [it/him].

(5) Nőtt, nőtt, nőtt a bendője. (I/136)

There grew, grew, grew his paunch.

HU/Szentkuthy: (1) Holnemvolt egyszer egy rátermett nigger.

There was once an able nigger.

(2) A hasában benne volt Páter Mac Trigger.

In his belly inside there was Father Mac Trigger.

Áldólag benne.

Blessingly inside [it].

A jóég tudja, hogy kotyvasztották. (219)

Heaven knows how [they] concocted it.

(3) Nézi ötszáz felesége,

His five hundred wives are all looking

(4) A hasába belefér-e,

If it fits inside his belly

(5) S úgy látják, itt ma minden lik kell. (220)

And they see today every hole would be needed.

The Gáspár version, not a recognizable limerick in Hungarian, preserves the McTrigger rhyme but leaves no space for ambiguity with the 'somethings' of the reverend, which/who unequivocally find(s) a new location; the wives eat their fill rather than revelling their fill, and the rhythm 
trickles unmolested. The intersection with the Plumtree ad, on the other hand, perfectly serves the two-directionality of the SL limerick, since it promises a nuptial. In addition, since Hungarian lacks grammatical genders, the relative pronoun supplies the ambiguity missing from the limerick proper, connoting both 'him', McTrigger, and 'it' (whatever of him the chieftain stomached). The ending comes rather as a deflation, since what grows bigger is only the (male) belly. Szentkuthy's version, a full-blown limerick, preserves the original's a abba rhyme pattern but the inserted line from the Plumtree ad reads more like an extension of the limerick (especially since blessing, benediction is the attribute of priests, i.e., fathers) and its connection to Plumtree's potted meat is problematic. The sexual overtones played on by the appropriation of the Plumtree verse, the use of 'Pater' for Reverend and the mention of holes, are nevertheless lost in the confusion between the second and fourth verse: if something is already emphatically inside, it cannot be looking for an entrance, unless narrative time is interfered with - hardly the point of the genre.

The "Corrected" Hungarian version produces a perfect Hungarian limerick, with an aabba rhyme pattern, that capitalizes the sexual allusions in the original:

Elökelő benga néger.

High-born huge Negro

Hittérítő-micsodából egy micsodát ebédel.

Of missionary-something something dines.

Ha van: boldogság hona.

If there is: happiness' abode.

A jóég tudja, hogy kotyvasztották.

Heaven knows how [they] concocted it.

(2) Hittérítö-hmt ebédel.

Missionary-ehm [he] dines.

Felesége ötven.

His fifty wives

Sápad, ájul, döbben.

Pale, faint, are shaken:

Mily tápláló ez az étel!

How consistent is this food!

Scientia Traductionis, n.8, 2010 
The translation version opts for a strategy of 'explicitation': in order to reinforce the structural connection, the limerick's $2^{\text {nd }}$ verse is repeated in the later passage, with the added difference that the 'somethings' of the missionary are rendered by different substitutes. If in the first occurrence of the verse, the 'somethings' are, incidentally, a common euphemism for the (male and female) sexual organ (the three-syllable word, used twice, completely upsetting the rhythm pattern of the limerick, like in the original), in the second occurrence Bloom falls upon the correct rhythm, so the er-ring leaves no doubt as to the one-syllable (taboo) word to be supplied. The version also has the advantage of making the inserted Plumtree ad instantly recognizable.

Now for the Romanian translation by Ivănescu:

(1) A fost odată un negru regal.

There was once a royal nigger.

(2) Care nu ştiu ce a făcut sau a mâncat nu ştiu ce dintr-un pastor venal.

Who did I don't know what or ate I don't know what from a venal minister.

Cu el, un adevărat paradis.

With him, a true paradise.

Dumnezeu ştie ce amestec mai e şi ăsta. (I/204)

God knows what mixture this is.

Cele cinci sute de soaţe ale lui toate

His five hundred wives all

S-au distrat atunci pe săturate,

Had a great time as they pleased,

Şi a ajuns mai mare, tot mai mare, colosal. (I/205)

And [he/it] grew bigger, ever bigger, colossal.

The full-blown limerick in the Romanian translation renounces the McTrigger name and opts for a venal minister, in order better to drive the joke home; in addition, it renders well the faulty rhythm of the limerick. The strong sexual overtones are enhanced by the prepositional phrase pe săturate ('to the satisfaction of (all) appetites'), while the word that rounds off the rhyme magnifies the event to Gargantuan dimensions.

Father McTrigger's palatable 'somethings' infest not only the 'sandwich passage', but also the ensuing conversation between Bloom and Davy Byrne with a layer of unorthodox connotations, as the limerick's last three verses are bracketed by a question about Molly's planned tour, to be 
organized by Boylan: 'Who's getting it up?' (8.772). Bloom's echoing of Davy Byrne's question (8.784: 'Getting it up?'), while cautiously glossing over Boylan's name, adds yet one more crux to the translators' ordeal. From the translation versions discussed here, only the "Corrected" Hungarian text addresses the double-entendre: "Ki hozza össze?" [Who brings (it/them) together?], while being a frequently used phrase for (informally) organizing an event, also connotes (informal) match-making, the bringing of two potential lovers together, so a psychologically disturbing resonance is carried across. The recurrence of the phrase (an echo from 'Lotus Eaters', 5.153) further illustrates the claim that the structural, linguistic and stylistic fine-tuning of Ulysses asks for a nodal translation practice, starting from (recurring) textual nuclei, rather than proceeding in a linear order.

\section{(8.115)}

'Only big words for ordinary things on account of the sound.'

Lestrygonians is an episode where particularly numerous examples of dislocutions, process- and impact-sent(ence)s trace the workings of the mind, capturing thought in its inchoative state. As a rule, such non-normative and seemingly faulty syntactic constructions are smoothed out, backnormalized in translation. Where there is an attempt made at transferring the deviation into the TL, the translator has to decide on what kind of nonnormative language use to rely. Furthermore, the TL grammar, syntax, word order conditions the possibilities of dislocuting: the transfer of the word order 'Kill me that would' (8.376) into Hungarian would lead to a complete loss of emphasis because such fronting of the verb is perfectly natural in Hungarian. The 'sandwich passage' offers one such impact-sentence where the fronting of 'hygiene' speaks of half-conscious associative processes, the deviant word order leading to semantic fumble:

'Hygiene that was what they call now' (emphasis added).

Here is how translators cope:

RO/Ivănescu: Era o chestie de igienă aşa se spune acum.

It was a question of hygiene that's what it is called now.

HU/Gáspár: Ma higiénének mondják.

Today they call it hygiene.

Scientia Traductionis, n.8, 2010 
HU/Szentkuthy: Higiénéből volt így, ahogy most az ilyet nevezik.

Out of hygiene that was, what it is now called.

HU/"Corrected": Higiénéből volt akkor így, ahogy most az ilyet

nevezik.

Out of hygiene that then was, what it is now called.

Szentkuthy's version, taken over into the "Corrected" text with an additional time adverbial, opts for the same impact-structure by fronting 'hygiene'. However, it shows far less dystax than the original: firstly, because of the rationalizing effect of the comma that divides the locution into two clauses, and second, because of the discursive, explanatory nature of the second sentence-tag. The use of commas between main and subclauses, a convention that is as strong in Hungarian as it is in German, drastically limits the possibilities of rendering syntactic or grammatical indeterminacy. In contrast, English, a highly isolating language, has unequalled possibilities of multiple grammatical linkings that result in general indeterminacy of syntax or meaning. Inflective languages (Romanian) which have to accord noun, adjective, verb/subject, attribute, predicate, complement in case, number, gender, or agglutinating ones (Hungarian) where modality, direction, person and number are expressed through morphemes agglutinated to the noun and verb, are always conditioned by these pre-determinations.

Ironing out, corrections do not only affect unruly, dystactic grammatical structures but also semantic mislays. Some pages earlier Bloom sympathetically contemplates Mrs Purefoy's ordeal of having one difficult childbirth after another - in the event, producing a full-blown pun, totally beyond translators' reach: 'They ought to invent something to stop that. Life with hard labour' (8.377). Humanely he calls for a social program to alleviate pain at childbirth:

Time someone thought about it instead of gassing about the what was it the pensive bosom of the silver effulgence. Flapdoodle to feed fools on. (8.380, emphases added)

The sentence repeats, to a fault, the 'high falutin stuff' read out by Ned Lambert in 'Aeolus' ('...'neath the shadows cast o'er its pensive bosom by the overarching leafage of the giants of the forest', 7.246, emphasis added). Bloom brings together two phrases not originally connected in Ned Lambert's example of second-rate literariness; "bosom" is the first to come to mind, the fronting resulting in a (semantically defective) possessive. 'Gassing' also has an eye to windy 'Aeolus', while the dismissal that follows shows, mutatis mutandis, Bloom the (unconscious) stylist, employing one of 
the figures of style of 'ERIN, GREEN GEM OF THE SILVER SEA'.19 Bloom's ready-made linguistic (art) object retroactively comments on the quality of texts brought together in the (literary, rhetorical) collage that is Aeolus. Translations tend to 'right' the semantic inversion:

RO/Ivănescu: ...în loc să-i tot dea zor cu ce era în sânul îngândurat al splendoarei de argint. Fleacuri să le fluturi prin faţa fleţilor. (I/190) [Aeolus:,,...umbrele aruncate pe sânu-i îngândurat de frunzişul boltit bogat al uriaşilor pădurii”, I/147]

...instead of keeping it on (diligently) about what was in the pensive bosom of the silver effulgence. Pecadilloes to flag in front of good-for-nothings.

HU/Gáspár: ...ne olyanokat fecsegjenek, hogy ezüst ragyogású merengő kebel. Bolondoknak való maszlag.” (I/127) [Aeolus: „merengö kebel", I/97]

...[they should] not chat [about] the silvery effulgent pensive bosom. Flapdoodle for fools.

HU/Szentkuthy: ....ahelyett hogy a hogyishívják hő kebelének ezüst tündökletességéről lafatyolnának. Olcsó játék hülye gyerekeknek. (205) [Aeolus: ,...bús kebleit gyásszal borítja a lombsürủ alvilág alagútján az öserdő órjásait ölelve”, 157] ...instead of lapping about whatisitcalled the ardent bosom's silver effulgence. Cheap game for idiot children.

HU/"Corrected": ..ahelyett, hogy, na hogy is volt, merengő kebelének ezüst tündökletességéről nyomnák a sódert. Halandzsa hiszékeny hülyéknek.

...instead of, well, how was it, going on chattering about the pensive bosom's silver effulgence. Gibberish for credulous dummies.

From the earlier translations examined, only Ivănescu's Romanian version renders the alliteration of the concluding remark in a memorable phrase, with a touch of the recondite about it; his version goes half-way to preserve the anomaly of the possessive phrase by anthropomorphizing 'silver effulgence'. All translations, however, observe Bloom's compression and

19 According to Partridge's Dictionary of Slang and Unconventional English, 'flapdoodle' - with the meaning 'empty talk, transparent nonsense' - appears in the idiom '[flapdoodle/the stuff] they feed fools on' in the 1830s. The arbitrarily formed word (akin to flabbergast) was used in $17^{\text {th }}-18^{\text {th }}$ century low colloquial English for the membrum virile (Partridge 401). 
transformation of what, in 'Aeolus', are two disparate phrases, 'bosom' coming first to mind. Gáspár's Hungarian version (incidentally employing a word for flapdoodle which is also idiomatically 'edible') transforms the English cluster into an adjectival construct, preserving the 'Aeolus' echo, while Szentkuthy's translation 'forgets' the self-reference involved, 'sorting out' the misplaced, stumbling possession. Like in many other instances, Szentkuthy's translation sensibly lowers the register, as if in an attempt to 'update' the original's linguistic and stylistic shock-effect to the sensibilities of the TL culture at the time of the translation's publishing: in his version 'flapdoodle', a linguistically defamiliarizing, rare word with historically layered meanings, is rendered by a widely used colloquial phrase with an aura of cheap insolence rather. The "Corrected" Hungarian text carries over the alliteration, while contrasting the shop-soiled loftiness of the 'Aeolus' echo with a dated slang phrase for 'gassing'. However, this version also rectifies the semantic fumble in Bloom's interior monologue, while the rigorous punctuation transforms the general indeterminacy and brokenness of Bloom's nascent thoughts into full grammatical and discursive coherence.

Bloom's interior monologue is choc-a-bloc with remembered phrases, advertisement slogans, shreds of (often defective) learning which make up a densely woven fabric of intertextual and intra-intertextual correspondences. The rendering of such nested quotes and echoes raises specific translation problems. The passage where Bloom expresses his sympathy with Mrs Purefoy is a good example for the various language games, literary allusions, translation problems involved:

Poor Mrs Purefoy! Methodist husband. Method in his madness. Saffron bun and milk and soda lunch in the educational dairy... And still his muttonchop whiskers grew... One tony relative in every family. Hardy annuals he presents her with. (8.358, emphases added)

The husband's denomination triggers a literary echo, Polonius's remark: 'Though this be madness, yet there is method in't' (Hamlet 2, 2), linking Purefoy's calculated lifestyle to the subtext of Hamlet's madness. The translator faces the additional difficulty of having to reach a compromise between the 'authoritative' translation version Hamlet in the TL and the imperative of providing the link from 'Methodist' to (Hamlet's/Purefoy's) method; a third aspect is alliteration which gives the phrase an axiomatic quality. The use of the Hamlet quote involves a further problem: since many of the Shakespearean texts are understandably far less embedded in the TLs and cultural memory examined here than they are in the SL, such links would not be at the hand of the average Hungarian/Romanian reader. The irony of 
'Method in his madness' or 'For this relief much thanks' (Hamlet 1.1; the phrase occurs in Nausicaa 13.940, where it plays on the multiple meanings of 'relief', immediately following on Bloom's ejaculation) would be largely lost on the non-English reader without annotations.

HU/Gáspár: Methodista férj. Methódus az őrültségében.

Methodist husband. Method in his madness.

HU/Szentkuthy, HU/"Corrected":

Metodista férj. Metódus a marhaságban...

Methodist husband. Method in his phoneyness.

RO/Ivănescu: Bărbatu-său e metodist. E metodă în nebunia lui.

Her husband is a Methodist. There is method in his madness.

The Hungarian versions reinforce the structural connection 'method - Methodist', employing the word of Greek origin and thus forsaking the Shakespearean allusion. ${ }^{20}$ Szentkuthy (again lowering register) produces a conspicuous and well-rounded alliterative phrase, to supply the 'literary', axiomatic character of the lost literary echo. Ivănescu, on the other hand, preserves the Hamlet quote almost verbatim, driving the (cultural, literary) interface home with the Romanian reader. ${ }^{21}$ Generally speaking, these translators' choices show Bloom either as the bricoleur of (others') words, or as a creator of memorable, axiomatic phrases.

The text presents a series of semantic obscurities, connected to realia, elements of Irish culture and Hiberno-English, some of which were certainly beyond the reach of early translators who didn't have the advantage of Gifford's notes and much of Joycean criticism. The rationale for the appearance of Purefoy's 'muttonchop whiskers' in the context of his educational

20 In János Arany's 'classic' nineteenth-century translation: 'Örült beszéd, őrült beszéd, de van benne rendszer" [Mad speech, mad speech, yet there is method in it]. Arany substitutes a homely Hungarian word, 'rendszer' [system, orderliness] for 'method' and no alliteration is observed; at the same time the quote, far from being axiomatic, sounds strangely colloquial, so that it could hardly reinforce the effect of heightened register proper to 'classical idiom'.

${ }^{21}$ Although the 'authoritative' Romanian Hamlet, as the 'authoritative' Romanian Shakespeare is the version translated by Leon Levițchi together with Dan Duţescu (1964), the version echoed in Ivănescu's text is taken from Vladimir Streinu's 1965 rendering: "Asta, deşi e nebunie, are-n ea şi metodă." [This, although it's madness, also has method in it.] (Tragedia lui Hamlet, Prinț al Danemarcei. 1965. Trad. Vladimir Streinu. Bucureşti: Editura pentru Literatură: 119.) In Leviţchi's rendering: „O fi asta scrânteală, dar e cu socoteală." [This may well be nonsense, yet it has sense in it.] (Hamlet. 1996. Trad. Leon Leviţchi, Dan Duţescu. Bucureşti: Editura Univers Enciclopedic: 72.)

Scientia Traductionis, n.8, 2010 
dairy (cf. Gifford 166) may well be a belief that meat-eating made (male) hair grow - which belief would thus be disproved by Purefoy's vegetarian diet and his constant output of 'hardy annuals' (cf. 'Stephen, here's something to make your hair curl': Portrait 30). A further irony of the text is also that it contrasts bigotry in vegetarian diet with a particular type of whiskers, named after a chunk of meat.

RO/Ivănescu: Şi cu toate astea favoriţii îi cresc ca cotletele de viţel..

Nevertheless, his whiskers / protegés are growing like veal cutlets.

HU/Gáspár: De a birkaszőr-pofaszakálla azért megnőtt. Yet his sheepshair-whiskers have grown.

HU/Szentkuthy: De a bakkonbartoló kotlettje szépen fejlődik még. But his [bak: goat/buck; barkó: whiskers; kotlett: cutlet] is developing nicely.

HU/"Corrected": A pofaszakálla mégis olyanra nőtt, mint két bárányszelet. Yet his whiskers grew [to the size of] two muttonchops.

The Romanian translator employs a wordplay: favoriţi (pl, whiskers) are also (somebody's) favourites, protegés - short-circuiting the sentence to the well-connected 'tony relatives'. Gáspár provides a literal rendering of the sentence; Szentkuthy, on the other hand, produces a flamboyant display of linguistic inventiveness that cannot be inscribed clearly into any of the directions mapped by the original. His translation text offers us a 'Wakean' Bloom who indulges in conjuring up near-portmanteaus: bakkonbartoló kotlett is a construct of uncertain semantic implications, (loosely) based on bak ('buck/goat', more generally: male animal), an artificial, self-invented word bartoló (present participle of a non-existent verb) and kotlett (cutlet); the cluster aurally plays upon barkó (whiskers). The phrase can be 'read' as an interface between Hungarian and German, 'Backenbart' and 'Kotelette' both meaning whiskers in German (Kotelette being also the word for cutlet, that is, a porky 'equivalent' of the muttonchop whiskers). Szentkuthy, of German extraction, knew several languages; he owned a copy of Anna Livia Plurabelle, tried his hand at translating passages from the (then) Work-inProgress and his own metafiction shows marked traces of Joycean (Ulyssean, as well as Wakean) influence. Putting such pronouncedly recondite and multilingual plays with language into Bloom's mouth is rather problematic, as the 'much-turned' hero is singled out in many chapters for his lack of verbal dexterity rather than for his skills in manipulating words. Yet it is to no 
slight extent on such (sometimes gratuitous) linguistic artifice that the fame of Szentkuthy's translation as congenial rests. ${ }^{22}$

One more problem sentence of the original concerns the punctuality of Purefoy's 'presents' to his wife:

Hardy annuals he presents her with.

RO/Ivănescu: Îi face cadou nevastă-sa în fiecare an câte unul pe cinste. His wife makes him a present every year a 'tony' one.

HU/ Gáspár: Nehéz ajándékot ad neki minden évben. Heavy [also: hard] present [he] makes [her] every year.

HU/Szentkuthy: Nejét minden évben újabb majommal lepi meg.

[His] wife [he] surprises every year with another monkey.

HU/"Corrected": Évelő. Minden évben meglepi a nejét egy újabb palántával. (143)

$[\mathrm{He}$ is]a hardy annual. Every year he surprises his wife with a new seedling.

The expression, again, seems to be triggered by the context of hard birth, 'life with hard labour'. Hardy annuals, according to Partridge, is a constantly recurring bill (in Parliament) or a (journalistic) stock subject; as a botanical term it is also used for perennials, thus a well-chosen attribute for vegetarian Purefoy. Ivănescu inverts the direction of the 'presents', making the husband the addressee; his translation, so to say, absolves Purefoy from the hard blame tacitly laid on him by the text, so that the sentence reinforces

22 In a preceding passage where Bloom fantasizes on an Amazonian widow keen on horseriding ('Strong as a brood mare some of these horsey women', 8.345) Szentkuthy's translation shows a similar contrivance: 'Az ilyen fartemiszek szívósabbak a tenyészkancánál' (204), where fartemisz plays on the name of Artemis and the Hungarian for 'bum, buttocks' (far), giving birth to a buxom 'bum-Artemis'. In the same passage, the sentence 'Born courtesan' (8.356) is rendered with the flamboyant phrase "Született nimfomáriája van" [appr., 'she has (is) an inborn nymphomaria] (HU/Szentkuthy 204). Many translation choices might give the impression that Szentkuthy was looking at the Ulysses text from, with a background knowledge of, the unbound semiosis of the Wake. A similar conclusion is reached by critic Dávid Szolláth, member of the translator team of the "Corrected" version, in his study of Szentkuthy's translation: 'the translator actualized the reading experience of the Finnegans Wake language - a language which already foreshadows the postmodern linguistic turn - in translating the previous work that can hardly be characterized with this conception of language...there is an unquestionable affinity between Szentkuthy's linguistic inventions and the word-ing strategies of the Wake', in 'Leletmentés..', p. 6 [my translation]. 
Purefoy's socially lucrative 'method' rather than the wife's ordeal. Gáspár's Hungarian translation replicates the word order of the original (which, however, comes natural to Hungarian, having next to no sense of defamiliarization) and focuses on the adjective. ${ }^{23}$ Szentkuthy's translation lowers the register, turning it into a low-keyed comment on children in general and taking the witticism out of it. The "Corrected" Hungarian text invents a sparkle of wit, choosing the botanical angle, as 'palánta' (seedling) is a mildly humorous colloquial term for child. The sequence is oddly appropriate for the protagonist's timid attempts at witticism, as the connection needs some elucidation.

If one is to decide on the degrees of translators' 'invisibility' vs. 'visibility', of domesticating vs. foreignizing translations, ${ }^{24}$ the translation that follows the original's strangeness most closely, straying thus furthest from normative language use, would probably be Endre Gáspár's first Hungarian version - strangely enough, for early translations of the book as a rule were more embedded in current literary conventions (e.g. naturalism). Ivănescu's Romanian translation should also be gathered with the foreignizing translations in so far as it attentively and sensitively follows the original's atypical linguistic forms, generating a Romanian text that is both 'invisible' and 'visible' - 'visible' since it also involves a high degree of bold linguistic play. ${ }^{25}$ The most 'visible' translation would be unquestionably Szentkuthy's 1974 Hungarian version which has the highest incidence of linguistic 'concoctions' and boldly punceptual games that sometimes prevail over, or quite ignore, the original's directions of meaning. This translation text - as well as the fiction of Szentkuthy - has contributed to the shaping of late twentieth-century Hungarian prose to a degree that can hardly be overlooked; however, the danger, as András Kappanyos has pointed out, ${ }^{26}$ is that

23 'One tony relative in every family': 'Minden családban egy nyomós rokon' (I/127) [One heavy - i.e., one who weighs heavy - relative in every family] - where the adjective also provides a byplay on gravity/gravidity, while (as a low colloquial form) also presenting strong sexual associations.

${ }^{24}$ Lawrence Venuti, The Translator's Invisibility: A History of Translation (London - New York: Routledge, 1995).

25 As Rodica Ieta writes in her essay on Ivănescu's translation informed by Venuti's theory, Ivănescu is 'a both visible and invisible translator. His intervention is visible in that he preserves the strangeness of the novel's language and invisible in that he also tries to remain faithful to the original.' 'James Joyce's Ulysses in Romanian: An Uncanny and Foreign Language', in Rosa Maria Bollettieri Bosinelli and Ira Torresi (eds.), Joyce Studies in Italy 10: Joyce and/in Translation (Roma: Bulzoni Editore, 2007) 119-134, p. 125.

26 András Kappanyos, 'Ulysses, a nyughatatlan' ['Ulysses, the restless'], in Átváltozások 1997, Vol. 10, 44-54. 
Szentkuthy's flamboyant style tends to dominate Joyce's text. It is against such translation practice and in favour of a more faithful and more dislocuting text that the translation principles of the upcoming Hungarian version have been established.

\author{
Erika Mihálycsa \\ mihalycsa@yahoo.com \\ Babes-Bolyai University, Romania
}

Scientia Traductionis, n.8, 2010 